\title{
Analisis Perikanan Tangkap Skala Kecil di TPI Pasir Studi Kasus : Nelayan KUB Mina Jaya
}

\author{
[Analysis of Small-Scale Fisheries in TPI Pasir \\ Case Study : Fishermen of KUB Mina Jaya]
}

\author{
Andri Wahyudi ${ }^{1,2}$, Dedi Sutisna ${ }^{2}$ \\ 1Politeknik Kelautan dan Perikanan Pangandaran \\ Desa Babakan, Kecamatan Pangandaran, Pangandaran, Jawa Barat 46396 \\ 2Politeknik Ahli Usaha Perikanan Jakarta, JI. AUP Bar. JI. Raya Pasar Minggu, RT.1/RW.9, Jati \\ Padang, Kec. Ps. Minggu, Kota Jakarta Selatan, Daerah Khusus Ibukota Jakarta 12520
}

\begin{abstract}
Abstrak
Latar belakang penelitian ini adalah sebagian besar nelayan di Kabupaten Kebumen khususnya di TPI Pasir adalah nelayan skala kecil. Walaupun demikian perikanan tangkap skala kecil mampu memberikan kontribusi terhadap perekonomian masyarakat khususnya di wilayah pesisir dan berkontribusi pada pendapatan daerah dari sektor perikanan. Tujuan dari penelitian ini adalah untuk mengidentifikasi permasalahan yang ada pada perikanan skala kecil di TPI Pasir khususnya di KUB Mina Jaya, studi kasus nelayan KUB Mina Jaya. Metode yang digunakan adalah wawancara dan observasi langsung kepada nelayan di TPI Pasir khususnya di KUB Mina Jaya. Hasil yang diperoleh adalah nelayan yang ada di TPI Pasir semua termasuk nelayan skala kecil (small scale fisheries) dengan kapal berbahan fiber berukuran $1 \mathrm{GT}$, mesin motor tempel $15 \mathrm{PK}$, alat penangkapan ikan berupa jaring insang (gillnet), lama waktu melaut satu hari (one day fishing), dan ilmu melaut diperoleh secara turun temurun dari orang tua atau saudara. Target utama nelayan di TPI Pasir adalah ikan bawal putih dan ikan layur. Kesimpulan penelitian ini adalah terdapat beberapa permasalahan yang dihadapi nelayan di TPI Pasir khususnya di KUB Mina Jaya. Permasalahan tersebut dilihat dari aspek manusia, metode, mesin, dan material.
\end{abstract}

Kata kunci : perikanan tangkap skala kecil; TPI Pasir; Kebumen.

\section{Abstract}

The background of this research is that most of the fishermen in Kebumen Regency, especially in TPI Pasir, are small-scale fishermen. However, small-scale capture fisheries are able to contribute to the economy of the community, especially in coastal areas and contribute to regional income from the fisheries sector. The purpose of this research is to identify problems that exist in small-scale fisheries at TPI Pasir, especially in KUB Mina Jaya, a case study of fishermen at KUB Mina Jaya. The method used is direct interview and observation to fishermen at TPI Pasir, especially at KUB Mina Jaya. The results obtained are all fishermen at TPI Pasir including small scale fisheries with 1 GT fiber boats, 15 PK outboard motor engines, gillnet fishing gear, one day long fishing time ( one day fishing), and knowledge of fishing is obtained from generation to generation from parents or siblings. The main targets of fishermen at TPI Pasir are white pomfret and layur fish. The conclusion of this research is that there are several problems faced by fishermen at TPI Pasir, especially at KUB Mina Jaya. These problems are seen from the aspects of humans, methods, machines and materials.

Keywords : small-scale fisheries; TPI Pasir; Kebumen. 


\section{Penulis Korespondensi}

Andri Wahyudi | wahyudi.andri8899@gmail.com

\section{PENDAHULUAN}

Aktivitas penangkapan ikan di Indonesia didominasi oleh nelayan kecil. Lebih dari 90\% nelayan Indonesia adalah nelayan kecil yang menangkap ikan di daerah pesisir. Hal tersebut menjadi peluang yang besar sekaligus tantangan untuk memperkuat usaha perikanan tangkap skala kecil agar lebih maju, mandiri, dan berkelanjutan (Siaran Pers KKP, 2020). Di dalam UU No.7/2016 tentang Perlindungan dan Pemberdayaan

Nelayan,

Pembudidaya Ikan dan Petambak Garam mendefinisikan nelayan kecil sebagai nelayan yang melakukan penangkapan ikan untuk memenuhi kebutuhan hidup sehari-hari, baik yang tidak menggunakan kapal penangkap ikan maupun yang menggunakan kapal penangkap ikan berukuran paling besar 10 (sepuluh) gros ton (GT). Nelayan kecil secara umum dipandang oleh pemerintah sebagai kelompok masyarakat miskin, termarjinalkan dan rentan terhadap guncangan sosial dan ekonomi, sehingga pada tingkatan tertentu memerlukan dukungan dan perlindungan sosial dan ekonomi (Halim et al., 2019). Namun demikian, dengan jumlah yang lebih mendominasi, perikanan skala kecil mempunyai peranan penting dalam mendukung pembangunan sektor kelautan dan perikanan. Perikanan skala kecil menyediakan mata pencaharian dan ketahanan pangan bagi nelayan skala kecil dan masyarakat lokal di wilayah pesisir yang sebagian besar tergantung pada sumber daya perikanan laut (Wardono, 2015 dalam LPSPL Sorong, 2020).

Kabupaten

Kebumen merupakan salah satu kabupaten di wilayah selatan Provinsi Jawa Tengah yang berbatasan langsung dengan Samudera Hindia. Sehingga, banyak masyarakat Kebumen yang berprofesi sebagai nelayan, terutama yang tinggal di wilayah pesisir. Hampir semua nelayan yang ada di Kabupaten Kebumen yaitu nelayan skala kecil dengan kapal rata-rata berukuran 1 GT dan waktu melaut hanya satu hari (one day fishing). Tujuan dari penelitian ini adalah untuk mengidentifikasi permasalahan yang ada pada perikanan skala kecil di TPI Pasir khususnya di KUB Mina Jaya, studi kasus nelayan KUB Mina Jaya.

\section{BAHAN DAN METODE}

Penelitian ini dilakukan di Desa Pasir Kecamatan Ayah Kabupaten Kebumen selama 1 bulan. Metode 
yang digunakan dalam penelitian ini adalah wawancara kepada nelayan di Desa Pasir Kecamatan Ayah Kabupaten Kebumen untuk mendapatkan data sekunder. Observasi dilakukan langsung yang dimulai dari mengikuti proses persiapan melaut sampai dengan lelang hasil tangkapan di TPI Pasir. Responden adalah kelompok KUB Mina Jaya, tiga nelayan, yang dipilih menggunakan metode purposive sampling berdasarkan kriteria sebagai nelayan aktif dan melaut secara one day fishing. Alat yang digunakan pada penelitian ini adalah kuesioner dan kamera. Data hasil penelitian disajikan dalam tabel dan grafik secara deskriptif.

\section{HASIL DAN PEMBAHASAN}

Hasil

Nelayan merupakan jenis pekerjaan yang digeluti secara turun menurun dari orang tua maupun saudara. IImu melaut atau menangkap ikan dipelajari dengan praktek langsung mengikuti kegiatan para nelayan senior. Istilah di kalangan nelayan dengan ilmu kirakira (feeling) atau dalam bahasa Jawa ada yang menyebut dengan "ilmu titen". Nelayan yang ada di TPI Pasir khususnya di KUB Mina Jaya tergolong ke dalam nelayan kecil atau nelayan tradisional, yang beroperasi menggunakan kapal kecil/perahu berbahan fiber ukuran 1 GT, mesin tempel $15 \mathrm{PK}$, berawak dua orang dengan cara kerja dan peralatan yang masih sederhana. Data kepemilikan jumlah kapal pada KUB Mina Jaya disajikan pada Tabel 1.

Tabel 1. Kepemilikan Jumlah Kapal

\begin{tabular}{ccl}
$\begin{array}{c}\text { Nama } \\
\text { Kelompok } \\
\text { KUB }\end{array}$ & $\begin{array}{c}\text { Jumlah } \\
\text { Kapal } \\
\text { (unit) }\end{array}$ & $\begin{array}{c}\text { Alat } \\
\text { Tangkap }\end{array}$ \\
\hline Mina Jaya & 16 & $\begin{array}{l}\text { Jaring } \\
\text { insang } \\
\text { (gillnet) }\end{array}$ \\
\hline
\end{tabular}

Sumber : Penulis (2021)

Pada waktu melaksanakan penelitian (bulan Januari), keadaan laut sedang sering berombak besar atau angin kencang. Sehingga, nelayan banyak yang tidak dapat melaut. Pada tanggal 12 Februari 2021 nelayan berlayar menggunakan Kapal Ilham P. bersama ketua KUB Mina Jaya untuk melakukan kegiatan penangkapan ikan selama 1 hari berlayar. Gambar 1 menunjukkan nelayan bersiap untuk berlayar menggunakan kapal Ilham P. Tabel 2 adalah data keragaan kapal Ilham $P$. 


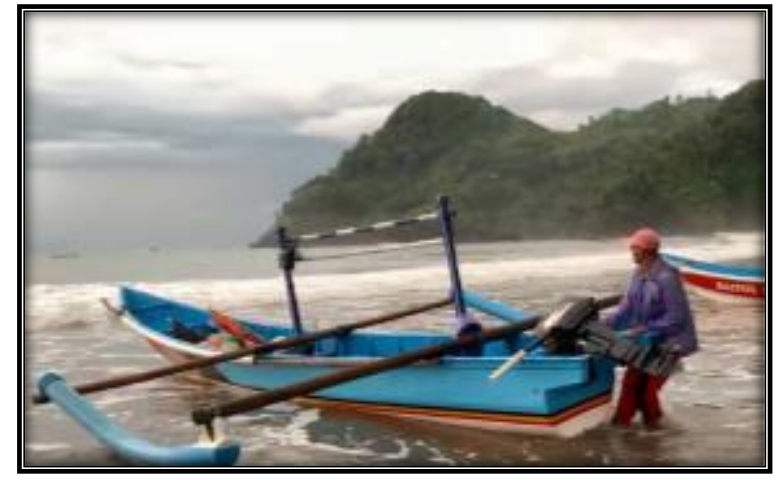

Gambar 1. Kapal Ilham P.

Tabel 2. Data kapal Ilham P.

\begin{tabular}{|c|c|c|}
\hline No. & Spesifikasi & Keterangan \\
\hline 1. & Nama kapal & Ilham P. \\
\hline 2. & Nama nelayan & $\begin{array}{l}\text { Wasijo dan } \\
\text { Sukendar }\end{array}$ \\
\hline 3. & Panjang kapal & $9,50 \mathrm{~m}$ \\
\hline 4. & Lebar kapal & $1,00 \mathrm{~m}$ \\
\hline 5. & Tinggi kapal & $0,68 \mathrm{~m}$ \\
\hline 6. & $\begin{array}{l}\text { Gross tonnage } \\
\text { (GT) }\end{array}$ & $1 \mathrm{GT}$ \\
\hline 7. & Bahan kapal & Fiber \\
\hline 8. & $\begin{array}{l}\text { Tahun } \\
\text { pembuatan }\end{array}$ & 2017 \\
\hline 9. & Merk mesin/PK & Suzuki/15 PK \\
\hline 10. & $\begin{array}{l}\text { Jenis } \\
\text { tangkap }\end{array}$ & $\begin{array}{l}\text { Jaring insang } \\
\text { (gillnet) }\end{array}$ \\
\hline
\end{tabular}

Kegiatan yang dilakukan di Kapal Ilham P. meliputi persiapan di darat sampai kembali dari kegiatan penangkapan ikan dan melakukan penjualan/lelang hasil tangkapan di TPI Pasir. Kegiatan tersebut antara lain sebagai berikut:

1. Persiapan

Sebelum berangkat melaut terlebih dahulu mempersiapkan kapal, alat tangkap, mesin, bbm dan konsumsi. Dalam menyiapkan kapal dibantu oleh regu/tim juru parkir yang berjumlah 6-8 orang. Gambar 2 adalah persiapan nelayan berangkat melaut.

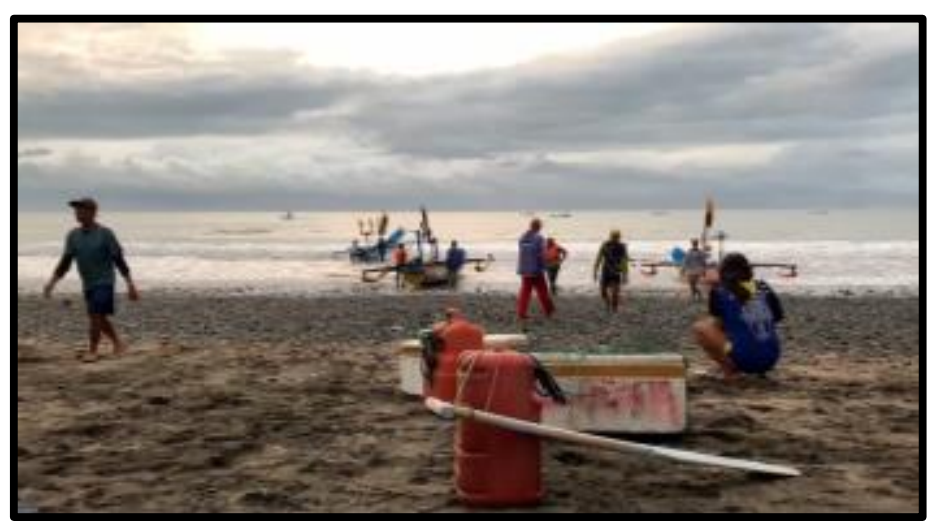

Gambar 2. Persiapan

2. Menuju daerah penangkapan Dalam menentukan daerah ikan (fishing ground) penangkapan ikan berdasarkan 
informasi dari nelayan lain yang sebelumnya sudah berangkat, baik pada hari itu maupun hari sebelumnya. Dimana ada ikan disitu nelayan menyerbu. Setelah kurang lebih perjalanan 1 jam 15 menit ke arah timur, nelayan memutuskan berhenti dan mencoba untuk menebar jaring. Gambar 3 adalah nelayan sedang berlayar menuju lokasi penangkapan ikan.

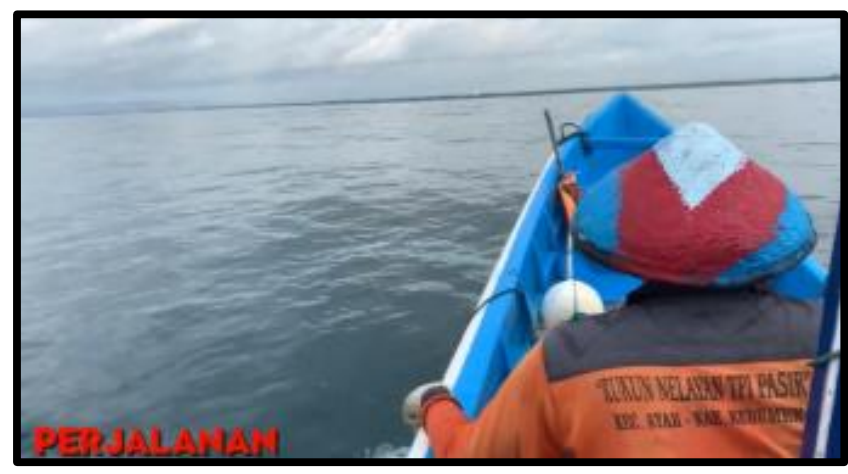

Gambar 3. Menuju daerah penangkapan ikan

3. Menebar jaring (setting)

Setelah kapal berhenti, nelayan mulai menebar jaring secara perlahan. Pada hari itu menebar jaring dilakukan sebanyak 6 (enam) kali. Gambar 4 adalah nelayan sedang menebar jaring.

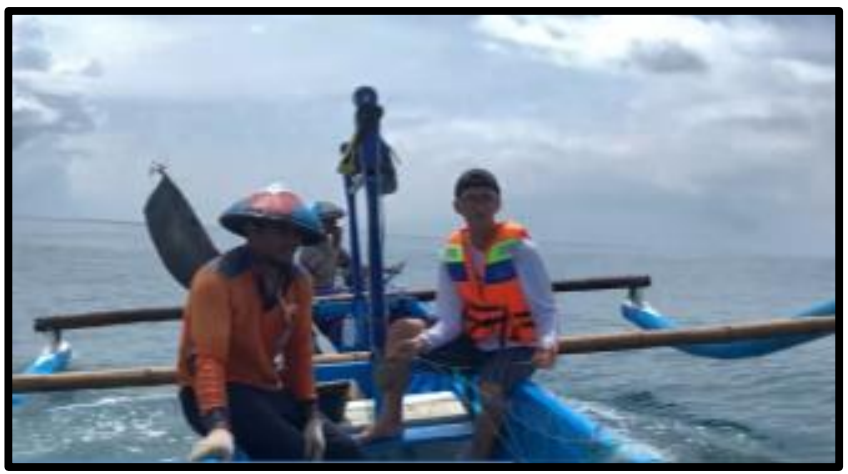

Gambar 4. Menebar jaring (setting)

4. Menarik jaring (hauling)

Dalam 1 kali menebar jaring memakan waktu 15-30 menit. Setelah jaring ditebar, dibiarkan

kurang lebih selama 1 jam. Jaring ditarik, dan diperiksa apakah ada ikan yang tersangkut atau tidak. Apabila ikan yang tersangkut banyak, maka jaring ditebar kembali pada titik tersebut. Apabila tidak ada ikan yang tersangkut, nelayan memutuskan untuk pindah/bergeser ke titik yang lain. Gambar 5 adalah nelayan 
melakukan kegiatan menarik

jaring.

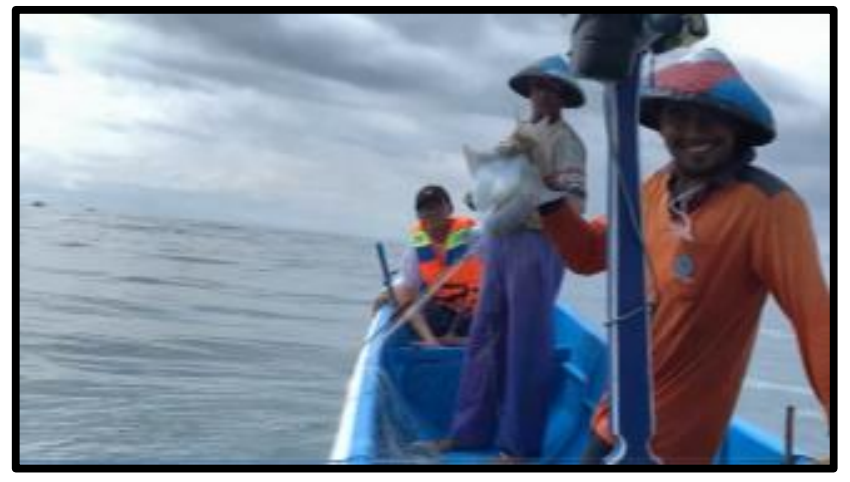

Gambar 5. Menarik jaring (hauling)

5. Kembali/pulang ke daratan

Kegiatan menebar dan menarik jaring semua masih dilakukan secara manual dengan tenaga manusia. Setelah melakukan 6 kali setting dan hauling, hasil tangkapan sudah dirasa cukup, nelayan memutuskan untuk pulang, karena mereka sudah kelelahan. Gambar 6 adalah nelayan yang melakukan perjalanan pulang ke darat.

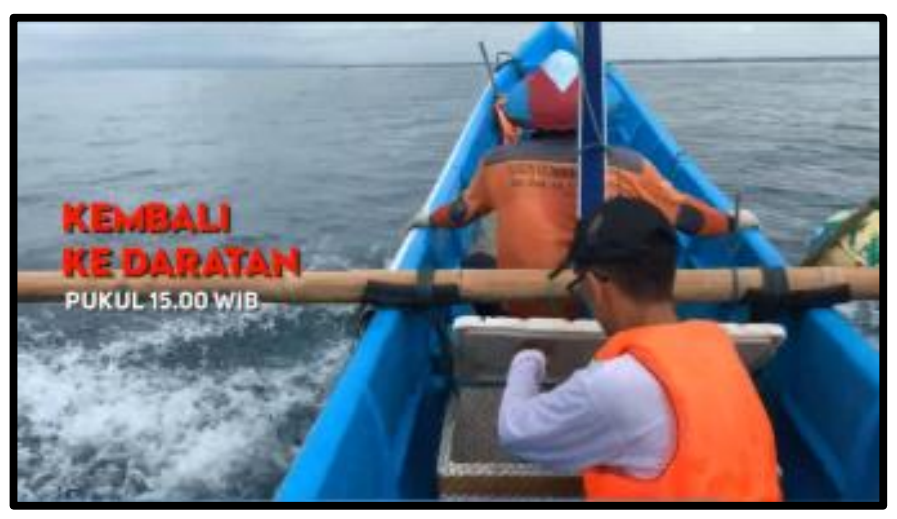

Gambar 6. Perjalanan Pulang

6. Menjual hasil tangkapan (lelang di TPI). Hasil tangkapan dibawa ke TPI Pasir untuk dijual dengan proses lelang. Hasil tangkapan ikan pada hari itu sekitar $29 \mathrm{~kg}$ ikan bawal putih. Gambar 7 adalah kegiatan perikanan di TPI. 


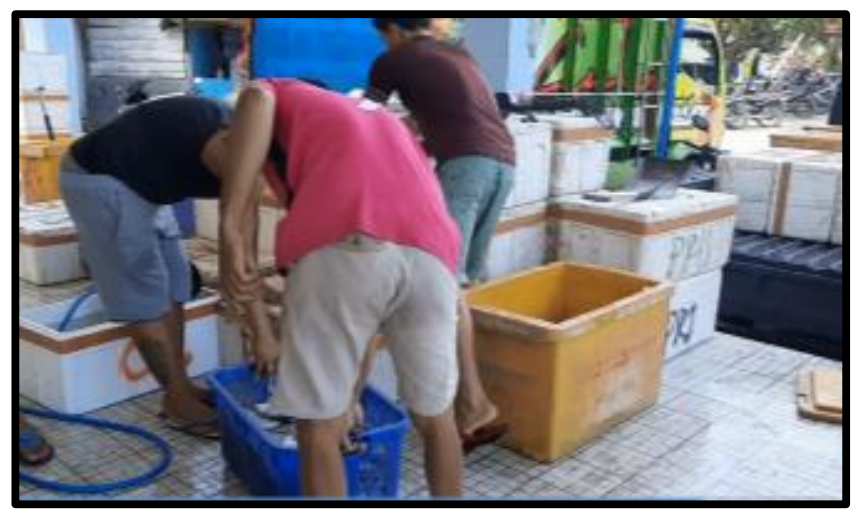

Gambar 7. Aktifitas Lelang di TPI Pasir

Biaya produksi merupakan biaya yang dikeluarkan selama proses penangkapan. Jumlah biaya produksi tergantung dari bagaimana cara operasi unit penangkapan tersebut melakukan operasi penangkapan. Biaya tidak tetap atau biaya variabel yaitu biaya yang jumlahnya berubah-ubah setiap operasi penangkapan yang dikeluarkan selama 1 trip penangkapan. Biaya tidak tetap terdiri dari biaya untuk bbm, perbekalan/konsumsi, juru parkir kapal dan jasa angkut mesin. Biaya produksi yang dikeluarkan dalam 1 trip selama mengikuti kapal Ilham P. dapat dilihat pada Tabel 3 di bawah ini.

Tabel 3. Biaya Produksi Per Trip Pada Kapal Ilham P.

\begin{tabular}{llllll}
\hline No. & \multicolumn{1}{c}{ Jenis } & Volume & Satuan & $\begin{array}{c}\text { Harga/satuan } \\
(\mathrm{Rp})\end{array}$ & $\begin{array}{c}\text { Jumlah } \\
(\mathrm{Rp})\end{array}$ \\
\hline 1. & BBM & 20 & liter & 10.000 & 200.000 \\
2. & Perbekalan/konsumsi & 1 & trip & 100.000 & 100.000 \\
3. Juru parkir kapal & 1 & trip & 300.000 & 300.000 \\
4. Juru angkut mesin & 1 & trip & 30.000 & 30.0000 \\
Jumlah & & & & 630.000 \\
\hline
\end{tabular}

Sumber : Penulis (2021)

Pendapatan dari hasil penjualan ikan bawal putih $29 \mathrm{~kg}$ sebesar $\mathrm{Rp}$ 6.890.000,- Sehingga pendapatan bersih yang diperoleh pada hari itu sebesar Rp 6.260.000,- Kapal Ilham P. merupakan kapal milik sendiri, sehingga pendapatan bersih dari hasil menangkap ikan tersebut dibagi dua (ABK: 2 orang).

Apabila kapal yang digunakan milik juragan (bukan milik sendiri), pembagian hasil pendapatan bersih dari kegiatan menangkap ikan yang 
sudah berjalan di TPI pasir sebesar $30 \%$ untuk juragan (pemilik kapal) dan $40 \%$ untuk nelayan. Satu kapal rata-rata dioperasikan oleh 2 orang nelayan ABK, sehingga masingmasing mendapat bagian $20 \%$.

Pada produksi ikan yang dihasilkan oleh nelayan di TPI Pasir terdapat beberapa kendala atau permasalahan. Kendala tersebut jika diberikan solusi yang tepat diharapkan dapat meningkatkan produksi. Permasalahan tersebut telah dianalisis menggunakan fish bone diagram seperti pada Gambar 8 dan hasilnya sebagai berikut:

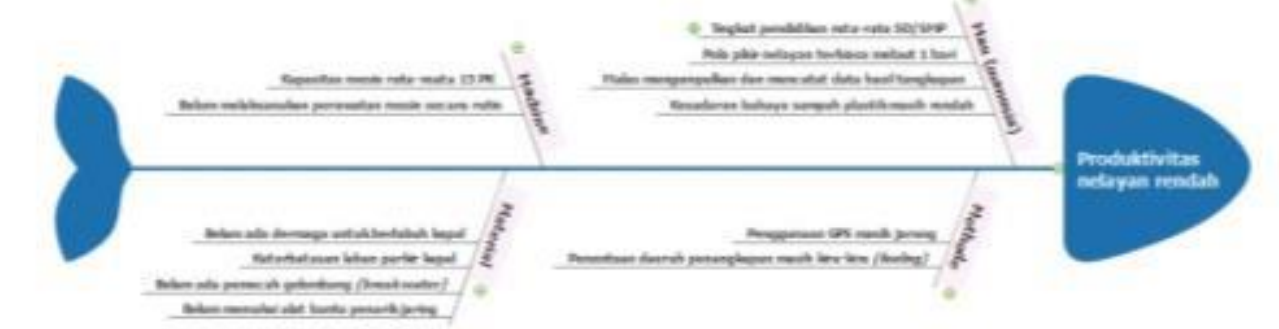

Gambar 8. Fish Bone Diagram

Man (Manusia)

Sumber Daya Manusia (SDM) dalam hal ini nelayan memiliki peranan penting dalam pengoperasian unit penangkapan ikan. Pengetahuan, keterampilan, dan ketelitian dari SDM dalam melakukan pekerjaan menjadi faktor untuk meningkatkan produksi jumlah ikan dari suatu unit penangkapan. Permasalahan yang dihadapi berhubungan dengan faktor manusia adalah sebagai berikut:

1. Tingkat pendidikan
Pendidikan rata-rata nelayan lulusan SD dan SMP

2. Pola pikir nelayan

Seiring berjalannya waktu, dengan terbiasanya melaut hanya 1 hari (one day fishing), nelayan enggan untuk menambah hari melaut, nelayan hanya terpatok pada komoditas unggulan (ikan bawal putih dan ikan layur). Apabila kedua ikan tersebut sedang tidak musim, banyak nelayan yang memilih tidak melaut.

3. Pencatatan data

Sebagian besar nelayan masih malas untuk mengumpulkan dan 
mencatat data hasil kegiatan penangkapan ikan. Ada pemikiran dari nelayan, yang penting pulang bawa uang bukan bawa tulisan (data). Padahal dengan adanya data, nelayan dapat melakukan evaluasi kegiatan yang sudah dilaksanakan.

4. Sampah plastik

Kesadaran nelayan dan masyarakat umumnya akan bahaya sampah plastik masih rendah. Terlihat dari banyaknya sampah plastik yang mengapung di laut dan ikut terjaring di jaring nelayan. Sampah yang terkena jaring nelayan, dibuang lagi ke laut. Bahkan sampah sisa dari nelayan itu sendiri dibuang juga ke laut. Hal ini dapat membahayakan kelestarian ekosistem laut dan sumber daya ikan yang ada.

\section{Methode}

Permasalahan yang disebabkan kesalahan pada metode pada umumnya didasari tidak adanya Standar Operasional Prosedur (SOP) dalam melaksanakan pekerjaan. Lebih khusus permasalahan yang dimaksud disebabkan oleh faktor metode adalah sebagai berikut:

1. Penggunaan GPS
Nelayan masih jarang yang

menggunakan GPS untuk menandai daerah penangkapan ikan, sehingga tidak tahu titik-titik mana yang biasanya banyak terdapat ikan

2. Penentuan daerah penangkapan ikan

Nelayan dalam menentukan daerah penangkapan ikan masih berdasarkan informasi dari nelayan lain, menggunakan ilmu kira-kira (feeling)

\section{Machine}

Mesin memegang peranan penting dalam proses produksi. Faktor penggunaan mesin sebagai alat bantu pada proses penangkapan ikan diharapkan dapat meningkatkan produksi ikan. Faktor penggunaan mesin yang dapat menyebabkan kendala antara lain:

1. Kapasitas mesin

Hampir semua nelayan di TPI Pasir menggunakan mesin kapasitas 15 PK baik dari merk Yamaha maupun Suzuki. Kapasitas mesin tersebut tidak mampu untuk melebihi daerah penangkapan lebih dari $12 \mathrm{mil}$

2. Perawatan mesin

Sebagian besar nelayan di TPI Pasir belum melaksanakan perawatan mesin secara rutin. Mesin akan dibawa ke bengkel apabila benar-benar sudah tidak dapat digunakan (mati). Sehingga 
sering terjadi mesin tiba-tiba rusak/mati pada saat digunakan untuk melaut.

\section{Material}

Secara umum faktor material yang menjadi permasalahan nelayan di TPI Pasir sebagai berikut:

1. Dermaga

Di TPI Pasir belum ada dermaga untuk berlabuh kapal. Selama ini kapal nelayan dari dan ke laut dengan cara dipikul oleh tim/regu juru parkir (6-8 orang).

2. Lahan parkir kapal

Kapal nelayan yang bersandar di TPI Pasir sampai dengan saat ini berjumlah 324 unit. Kapal tersebut parkir di bibir pantai/lahan parkir yang disediakan. Keterbatasan lahan dan banyaknya batu menjadi kendala. Batu-batu tersebut dapat menyebabkan kapal retak/pecah.

3. Pemecah gelombang (break water)

Pantai selatan Kebumen memiliki ombak yang lumayan tinggi. Pada saat angin timur, semua nelayan di TPI Pasir tidak bisa pergi melaut. Nelayan dengan kapal 1 GT tidak mampu untuk menerjang ombak dari bibir pantai menuju ke laut.

4. Alat bantu penarikan jaring

Nelayan melakukan penebaran dan penarikan jaring dengan cara manual. Dengan awak kapal yang rata-rata 2 orang, apabila sudah melakukan penebaran dan penarikan jaring lebih dari 5 kali, tenaga mereka sudah berkurang Apabila sudah kelelahan nelayan memilih untuk pulang.

\section{Pembahasan}

Nelayan skala kecil memberi kontribusi yang sangat besar dalam produksi perikanan tangkap Indonesia. Akan tetapi kemiskinan masih diidentikkan dengan nelayan, khususnya nelayan skala kecil. Hal ini menunjukkan usaha perikanan skala kecil masih tidak efisien, dimana upaya penangkapan melebihi ketersediaan dari sumber daya yang ada (Wiyono dan Wahju, 2006). Hasil tangkapan ikan belum diikuti kesejahteraan nelayan. Menurut Tain (2013), terdapat 15 faktor dominan penyebab kemiskinan rumah tangga nelayan, yaitu: (1) Kelembagaan yang merugikan nelayan kecil, (2) Program yang tidak memihak nelayan kecil, (3) Pandangan hidup yang berorientasi akhirat saja, (4) Keterbatasan sumberdaya, (5) Ketidaksesuaian alat tangkap, (6) Rendahnya investasi, (7) Terikat hutang, (8) Perilaku boros, (9) Keterbatasan musim penangkapan, (10) Kerusakan ekosistem, (11) Penyerobotan wilayah tangkap, (12) Lemahnya penegakan hukum, (13) 
Kompetisi untuk mengungguli nelayan lain, (14) Penggunaan alat atau bahan terlarang, dan (15) Perilaku penangkapan. Dari 15 faktor dominan penyebab kemiskinan rumah tangga nelayan tersebut, pada hakekatnya kemiskinan yang membelenggu rumah tangga nelayan adalah kemiskinan yang menyangkut multidimensi.

Target utama ikan tangkapan dari nelayan di KUB Mina Jaya dan nelayan di TPI Pasir pada umumnya yaitu ikan bawal putih (Pampus argentus). Hal ini dikarenakan harga ikan bawal putih yang tinggi dan termasuk komoditas ekspor. Mutu dan berat ikan bawal mempengaruhi harga ikan bawal putih (Susanti, Bambang, dan Asriyanto, 2020). Harga ikan bawal berbeda-beda tergantung pada berat ikan. Pada ikan bawal dengan ukuran besar dan kecil, maka harga dipengaruhi oleh jumlah produksi, sedangkan harga ikan bawal putih ukuran sedang dipengaruhi oleh jumlah produksi dan mutu ikan (Nadyasari, Bambang, dan Fitri, 2013). Harga ikan bawal putih berkisar Rp. 145.000-Rp. 170.000 per kg.

Unsur manusia merupakan faktor kunci penting dalam suksesnya kegiatan penangkapan ikan skala kecil (Sudarmo et al. 2013). Permasalahan sosial utama yang terjadi dalam perikanan tangkap berkelanjutan adalah kondisi SDM masyarakat nelayan yang mayoritas masih kurang baik. Hal ini disebabkan oleh rendahnya pendidikan formal yang sebagian besar disebabkan oleh sulitnya sekolah atau akses di daerah pesisir. Kurangnya pendidikan ini berdampak sulitnya masyarakat nelayan untuk menerima transfer ilmu maupun transfer teknologi, sehingga sering terjadi pelanggaran (Bappenas, 2018).

Rendahnya tingkat pendidikan nelayan berpengaruh terhadap keterampilan, pola pikir, dan mental. Tingkat pendidikan sebagai salah satu indikator dari Kualitas Sumber Daya Manusia, indikator ini sangat menentukan seseorang atau sekelompok orang berstatus golongan masyarakat miskin atau bukan miskin, berpendidikan rendah, produktivitasnya rendah. Rendahnya produktivitas akan berpengaruh pada rendahnya pendapatan. Sedangkan, rendahnya tingkat pendapatan merupakan salah satu ciri dari penduduk miskin (Zebua et al., 2016).

Selama ini, penentuan daerah penangkapan ikan yang dilakukan oleh nelayan Indonesia terutama di Kabupaten Kebumen masih memanfaatkan tanda-tanda alam dan masih berdasarkan pengalaman nelayan- 
nelayan terdahulu (Negari, Triarso, dan Kurohman, 2017). Pemakaian teknologi maju yang sudah baku seperti GPS (Global Positioning System) sebagai alat bantu navigasi yang dapat memandu mereka mencari lokasi, sampai saat ini masih langka dimiliki nelayan tradisional di Kebumen. Kegiatan seperti ini menjadikan aktivitas penangkapan ikan kurang optimal karena tingkat ketidakpastian cukup tinggi dan akan berimbas pada biaya operasional (Firmansyah et al., 2018).

Kekuatan mesin perahu atau kapal yang digunakan nelayan berpengaruh terhadap jumlah tangkapan ikan, nelayan yang menggunakan perahu mesin memperoleh jumlah tangkapan yang lebih banyak dibandingkan yang tidak menggunakan mesin (Rahim, 2016). Semakin besar ukuran mesin tempel maka semakin besar daya tampung bensin, sehingga akan meningkatkan daya jelajah nelayan selanjutnya akan meningkatkan tangkapan (produksi) ikan (Esa dan Putra, 2016). Setelah adanya penggunaan teknologi mesin sebagai penggerak perahu dalam mencari ikan, ada satu hal yang tidak kalah penting dalam penggunaan teknologi mesin tersebut, yaitu perawatan atau pemeliharaan mesin itu sendiri agar kondisi tetap prima dan masa pakai lebih lama atau lebih awet. Pengoperasian mesin adalah faktor yang sangat menentukan agar masa pemakaian mesin sesuai dengan masa perbaikan, sehingga aturan dalam pengoperasian mesin itu sendiri menjadi sangat penting untuk diperhatikan dan dilaksanakan sesuai dengan patokan standard (Handoko dan Shah, 2019). Penggunaan mesin tidak akan lebih baik apabila nelayan kurang atau tidak peduli terhadap kesehatan mesin (Ulum et al., 2019).

Belum adanya dermaga di TPI Pasir mengakibatkan kurang efektif dan efisiennya kegiatan bongkar muat kapal nelayan. Setiap mau berangkat dan pulang melaut, kapal nelayan harus dipikul oleh beberapa tenaga manusia, yang akhirnya menambah biaya produksi. Nelayan di TPI Pasir sangat mengharapkan adanya dermaga di wilayah tersebut. Fasilitas dermaga memberikan banyak kemudahan bagi kapal ikan untuk membongkar ikan hasil tangkapan dan dengan adanya dermaga hasil tangkapan lebih terjamin mutunya (Suherman dan Dault, 2009). TPI Pasir belum memiliki dermaga dan kolam pelabuhan. Sehingga kapal nelayan parkir di daratan dengan cara dipikul. Banyaknya batu di daratan terkadang mengakibatkan kerusakan 
kapal seperti retak atau kebocoran kapal. Kolam pelabuhan merupakan daerah perairan di pelabuhan untuk masuknya kapal-kapal yang bersandar di dermaga (Lubis 2012 dalam Pujiastuti, Irnawati, dan Rahmawati, 2018). Tingginya gelombang pantai selatan Jawa termasuk perairan di TPI Pasir memerlukan skill dan pengalaman khusus untuk melewatinya. Apalagi di TPI Pasir belum ada pemecah gelombang (breakwater), sehingga resiko kapal terbalik masih cukup besar. Apabila gelombang sedang tinggi-tingginya, nelayan memilih tidak melaut walaupun saat itu sedang banyak/musim ikan. Hal ini tentu sangat disayangkan. Besar harapan nelayan untuk dibangunnya breakwater di perairan TPI Pasir. Fungsi breakwater adalah bangunan penahan/meredam gelombang yang akan masuk ke dalam kolam dan alur pelabuhan (Samudra, Jasin, dan Halim, 2018). Nelayan di TPI Pasir dalam menebar (setting) dan menarik (hauling) jaring masih secara manual dengan tenaga 2-3 orang. Selain beresiko terhadap keselamatan kerja, hal tersebut juga mengakibatkan cepat kelelahan. Sehingga, perlu adanya alat bantu penarik jaring yang dapat diaplikasikan pada kapal nelayan skala kecil. Dengan menggunakan alat bantu penarikan jaring dapat menghemat tenaga kerja dan logistik, meningkatkan pendapatan nelayan, serta mempermudah penarikan jaring pada saat jaring harus diangkat (Rahanra dan Tampubolon, 2019).

\section{SIMPULAN DAN SARAN}

\section{Simpulan}

Kesimpulan hasil penelitian menunjukkan beberapa permasalahan yang dihadapi nelayan di TPI Pasir antara lain tingkat pendidikan nelayan rata-rata SD dan SMP, pola pikir nelayan yang sudah nyaman dengan pola one day fishing, lemahnya pencatatan data, kesadaran tentang sampah plastik masih rendah, nelayan masih jarang yang menggunakan GPS, penentuan daerah penangkapan ikan masih dengan ilmu kira-kira, kapasitas mesin yang digunakan hampir semuanya menggunakan mesin 15 PK, perawatan mesin secara rutin/berkala masih jarang dilakukan, belum adanya dermaga di TPI Pasir, terbatasnya lahan parkir kapal di bibir pantai, belum adanya pemecah gelombang, dan penarikan jaring masih dilakukan secara manual dengan tenaga manusia.

\section{Saran}

Saran dari hasil penelitian ini adalah untuk meningkatkan produktivitas dan keselamatan kerja nelayan, kapal yang menggunakan 
alat tangkap jaring insang (gillnet) dengan 2 (dua) orang $A B K$, perlu adanya alat bantu penangkapan untuk menarik (hauling) jaring.

\section{PERSANTUNAN}

Ucapan terima kasih ditujukan kepada Politeknik Ahli Usaha Perikanan Jakarta, Politeknik Kelautan dan Perikanan Pangandaran, Dinas Kelautan dan Perikanan Kabupaten Kebumen, Penyuluh Perikanan, TPI Pasir, Rukun Nelayan TPI Pasir dan KUB Mina Jaya serta semua pihak yang telah memfasilitasi kegiatan penelitian ini.

\section{DAFTAR PUSTAKA}

Bappenas. 2018. "Bab 6 Isu Strategis Dan

Permasalahannya 6.1." Isu Strategis Dan

Permasalahannya 1-15.

Esa, Gede, and Anggara B. Putra.

2016. "Analisis Faktor-FAktor

Yang Mempengaruhi Produksi

Dan Pendapatan Nelayan Di

Desa Batununggul Kecamatan

Nusa Penida." E-Jurnal EP Unud 8(5):1092-1121.

Firmansyah, Teguh, Zahidah Hasan, Eddy Afrianto, and Izza M. Apriliani. 2018. "Pemetaan Daerah Penangkapan Potensial Ikan Layur (Trichiurus Sp) Di Perairan Pangandaran, Jawa
Barat." Jurnal Airaha VII(1):612.

Halim, A., B. Wiryawan, N. R. Loneragan, A. Hordyk, M. Fed A. Sondita, Alan T. White, Sonny Koeshendrajana, Toni Ruchimat, Robert S. Pomeroy, and Christiana Yuni. 2019. "Merumuskan Definisi Perikanan Skala-Kecil Untuk Mendukung Pengelolaan Perikanan Tangkap Di Indonesia." Marine Policy 100:238-48.

Handoko, Catur Rahmat, and Muhammad Shah. 2019. "Pelatihan Pemeliharaan Mesin Tempel Kapal Pada Industri Galangan Kapal Untuk Meningkatkan Keterampilan Teknis Bidang Permesinan Kapal." Jurnal Cakrawala Maritim 2(2).

Nadyasari, Ardhana, A. .. Bambang, and A. D. .. Fitri. 2013. "Faktor Determinan Harga Ikan Bawal Putih (Pampus Argentus) Dari Hasil Tangkapan Cantrang Di TPI Asemdoyong Kabupaten Pemalang Jawa Tengah." Journal of Fisheries Resources Utilization Management Ang Technology 2(3):563-74.

Negari, Chobitta Arethuzsa Sekar, Imam Triarso, and Faik Kurohman. 2017. "Analisis Spasial Daerah Penangkapan 
Ikan Dengan Alat Tangkap Gill

Net Di Perairan Pasir,

Kabupaten Kebumen, Jawa

Tengah." Jurnal Perikanan

Tangkap 1(3):1-7.

Pujiastuti, Devi, Ririn Irnawati, and

Ani Rahmawati. 2018. "Kondisi

Dan Tingkat Pemanfaatan

Fasilitas Pangkalan Pendaratan

Ikan Kronjo Kabupaten

Tangerang Provinsi Banten (

Condition and Level Utilization

Facilities of Kronjo Fish Landing

Place Tangerang Regency

Banten Province )." Jurnal

Perikanan Dan Kelautan

8(1):40-55.

Rahanra, Nicodemus, and Irianty

Tampubolon. 2019.

"Pembuatan Alat Efektif Tarik Jaring ( Kapstan Gardan ) Guna Meningkatkan Pendapatan

Nelayan Tradisional Di

Kabupaten Teluk Wondama

Papua Barat." Jurnal Fateksa:

Jurnal Teknologi Dan Rekayasa 4(1).

Rahim, Abd. 2016. "Komparasi Hasil

Tangkapan Nelayan Tradisional

Wilayah Pesisir Pantai Barat

Kabupaten Barru." Jurnal

Kebijakan Sosial Ekonomi

Kelautan Dan Perikanan

3(1):107.

doi:

10.15578/jksekp.v3i2.312.

Samudra, A. R., M. I. Jasin, and F.

Halim. 2018. "Evaluasi Kinerja

Breakwater

Terhadap
Gelombang Di Kawasan

Pelabuhan Manado." Jurnal

Sipil Statik 6(4):211-24.

Sudarmo, Agnes P., Mulyono S. Baskoro, Budy Wiryawan, Eko

S. Wiyono, and Daniel $R$. Monintja. 2013. "Perikanan Skala Kecil: Proses Pengambilan Keputusan Nelayan Dalam Kaitannya Dengan Faktor-Faktor Yang Mempengaruhi Penangkapan Ikan." Marine Fisheries : Journal of Marine Fisheries Technology and Management 4(2):195.

Suherman, Agus, and Adhyaksa

Dault. 2009. "Dampak Sosial

Ekonomi Pembangunan Dan

Pengembangan Pelabuhan

Perikanan Nusantara (PPN)

Pengambengan Jembrana

Bali." Jurnal Saintek Perikanan

4(2):24-32.

Susanti, Ika, Azis Nur Bambang, and Asriyanto. 2020. "Analisis

Faktor-Faktor Yang

Mempengaruhi Terbentuknya

Harga Ikan Bawal Putih (Pampus Argenteus) Dengan Alat Tangkap Gill Net Di TPI Tegal Katilayu Kabupaten Cilacap." Journal of Fisheries Resources Utilization Management and Technology 3(3):284-91.

Tain, Anas. 2013. "Faktor Dominan Penyebab Kemiskinan Rumah Tangga Nelayan Motor Tempel 
Di Wilayah Tangkap Lebih Jawa Timur." Sosiohumaniora 15(1):35. doi: 10.24198/sosiohumaniora.v15i1 .5237 .

Ulum, Miftahul, Bambang Setyono,

Dwi Khusna, and Gatot Setyono. 2019. "Pengabdian Kepada Masyarakat Bagi Nelayan Nambangan Kelurahan Kedung Cowek Kecamatan Bulak 'Penyuluhan Perawatan Mesin Kapal Nelayan." Journal of Science and Social Development 2(2):43-48.

Wiyono, Eko Sri, and Ronny Irawan

Wahju. 2006. "Penghitungan Kapasitas Penangkapan ( Fishing Capacity ) Pada Perikanan Skala Kecil Pantai: Suatu Penelitian Pendahuluan." IPB University 381-89.

Zebua, Yemima, Pradinda Krisna Wildani, Andika Lasefa, and Riki Rahmad. 2016. "Faktor Penyebab Rendahnya Tingkat Kesejahteraan Nelayan Pesisir Pantai Sri Mersing Desa Kuala Lama Kabupaten Serdang Bedagai Sumatera Utara." Jurnal Geografi 9(1):88. doi: 10.24114/jg.v9i1.6923.

LPSPL Sorong. 2020. Pengelolaan

Perikanan Skala Kecil dengan Pendekatan Kearifan Lokal di Wilayah Timur Indonesia. https://kkp.go.id/djprl//psplsoron g/artikel/24663-pengelolaanperikanan-skala-kecil-denganpendekatan-kearifan-lokal-diwilayah-timur-indonesia.

Diakses pada tanggal 16 Desember 2020 pukul 21.19 WIB.

Siaran Pers KKP. 2020. Berdayakan Perikanan Skala Kecil, KKP Dorong Perikanan Nasional dan ASEAN.

https://kkp.go.id/artikel/23309-

berdayakan-perikanan-skala-

kecil-kkp-dorong-perekonomiannasional-dan-asean. Diakses pada tanggal 17 Desember 2020 pukul 03.15 WIB.

Undang-Undang Nomor 7 Tahun 2016 tentang Perlindungan dan Pemberdayaan Nelayan, Pembudidaya Ikan dan Petambak Garam. 